\title{
Designing an English Learning Module for English for Tour Guide Course in English Language Education Program of STKIP Siliwangi Bandung
}

\author{
Intan Satriani, Gartika Pandu Bhuana, Ula Nisa El Fauzia \\ Intan.satriani@yahoo.co.id \\ STKIP Siliwangi Bandung
}

\begin{abstract}
English for Tour Guide is one of the courses in English Language Education Program of STKIP Siliwangi Bandung. This course uses "English for Professional Tour Guiding Services" as a textbook. Various problems are found when the teachers use this book in the classroom. It predominantly deals with the materials. In response to this problem, this study aims to evaluate the use of "English for Professional Tour Guiding Services" book for students in English Language Education Program of STKIP Siliwangi Bandung. This research will apply quantitative and qualitative research design. There are two instruments in obtaining the data, namely questionnaire and interview. Through this study, it is expected that the strengths and weaknesses of this book can be found. Thus, the suitable materials for the students can be designed. For a long term, it is expected that the result of this study can be used as a reference to make a book of English for Tour Guide course.
\end{abstract}

Keywords: textbook evaluation, English for tour guide

\section{Introduction}

English for Tour Guide is one of courses in English Language Education Program at STKIP Siliwangi Bandung. This course is designed to help the students to communicate using English, whether it is verbally or non-verbally, in the context of tourism industry, especially tour guiding service. Varioustopics are discussed in this course. The main topic focuses on tour guide conversation, such as welcoming the tourist, giving information, etc. Another topic is related to the skill needed to be professional tour guide, how to make itinerary, tour package, and brochure; and how to make a report of tour activity.

As a reference, this course uses "English for Professional Tour Guiding Services" textbook written by Sutanto Leo. In general, the use of this book is really helpful for the teachers as it provides guides for the students to practice communication within tour guiding service. Unfortunately, in the application, various problems are found. The first problem deals with the overlap material, while the second one is related to material given in unsystematic way. Most of the material given on this book also only focuses on improving three language skills: speaking, reading, and writing. None of the material attempted to develop students' listening skill, as the use of audio or CD. As a matter of fact, this is receptive skill that should be learnt by English language students.

Regarding the above weaknesses, the evaluation of English for Tour Guide textbook is definitely needed. Evaluation, according to Lynch (cited in Tabaeifard, 2014), is the systematic attempt to gather information in order to make judgment or decision. Hutchinson 
and Water (in Fraidan, 2012) refers to evaluation as matching process, matching needs to available solution. Dealing with textbook evaluation, Harmer (2001) specifically points out that it is a judgment on how well a book has performed in fact. In short, textbook evaluation is systematic attempt to gather the information on how well a book has performed in teaching and learning process, whether or not it is suitable with need of students.

The above reason finally spurs the writers to conduct the study of the evaluation of English for Tour Guide textbook used by sixth semester students in English language education program of STKIP Siliwangi.

English for Tour Guide is one of courses in English Language Education Program at STKIP Siliwangi Bandung. This course is given to the sixth semester students. The aim is to help them to communicate using English, whether it is verbally or non-verbally, in the context of tourism industry, especially tour guiding service.

Various topics are discussed in this course. The main topic focuses on tour guide conversation. This includes welcoming the tourist; giving information; orientation meeting and briefing; explaining safety, rules, and etiquette; and closing or reporting tour activity. Another topic is related to the skill needed to be professional tour guide, how to make itinerary, tour package, and brochure; and how to make a report of tour activity.

As a reference, this course uses "English for Professional Tour Guiding Services" textbook. This book is written by an experienced academic instructor of the language, Sutanto Leo, and was published in 2016. The book is basically intended for pre-intermediate tourism students. However, it also can be used by general students as it contains the basis of the current theories and practice of tour guide services.

Needs analysis, also known as needs assessment, has a vital role in the process of designing and carrying out any language course. This centrality has been acknowledged by several scholars and authors (such as Hutchinson and Waters, 1987; Dudley-Evans and St. John, 1998; Iwai et al. 1999; \& Finney, 2002).

According to Iwai, Kondo, Lim, Ray, Shimizu \& Brown (1999), needs analysis is defined as collecting information from a selective group of students with the intent of developing a curriculum that meets their learning needs. In the case of language program, those needs will be language related. Once identified, needs can be stated in terms of goals and objectives which, in turn, can serve as the basis for developing tests, materials, teaching activities, and evaluation strategies.

Regarding this, Shahriari and Behjat (2014) present a similar thought. They say that the goal of the needs-analysis is to determine what a particular group of learners expects. Students' expectation will be actualized firstly in a course design, which provides relevancy for all course design activities and places the learners' purposes in the central position within its framework, and lastly in a curricula" (Shahriari \& Behjat, 2014).

Tomlinson (1998) defines material as anything which is used by the teacher and learners to facilitate the learning of a language. This statement is in line with Brown (1995) 
who states that material is any systematic description of a technique and exercise to be used in classroom teaching. Material in language teaching can be in the form of a textbook, a workbook, a cassette, a video, and anything which present or informs about the language being learned.

Material can be instructional, experimental, elicitative or exploratory (Harsono, 2007). The material can be instructional when it informs the learners about the language. It is experimental when it provides exposure to the language in use. It is elicitative when it stimulate language use, and exploratory when it seek.

\section{Research Methodology}

This research employed a mix method strategies consisted of quantitative and qualitative. Mix method strategies in this research are interview (qualitative data) which was combined with traditional surveys (quantitative) (Sieber, 1973 in Cresswell, 2009). This approach was be used to decrease bias of any single method.

In line with that definition, this research was conducted to explore students' satisfaction of the "English for Professional Tour Guiding Services" textbook from sixth semester students" point of view. Besides that, this research also used to find out the strengths and weaknesses of students' point of view.

A survey research design has been considered appropriate for this study, since it is in line with this study to describe situation which generalized findings to real world settings (Muijs, 2004). He also explained that survey studies are also efficient in terms of being able to gather large amounts of data at reasonably low cost and effort compare to another method like observation. Besides that, this design also suit for canvassing opinions and feelings about particular issues, especially in this study about textbook evaluation.

\section{Research Subject}

a. Population

Population of this research was all classes which attended English for tour guide course. The course was conducted to sixth semester students' year 2014.

b. Sample

The samples of population were taken purposively. They consisted of three classes with 30 students in each class. They were chosen for two reasons. First, the students had conducted English for tour guide course. Second, using textbook in professional development has been associated with the potential for teachers to develop creative materials and curriculum autonomy (Chu Ying and Young, 2011). On the point of that, the use of textbook was important for pre-service teacher. 
Data collection technique

There were two instruments used to obtain the data. These instruments were questionnaire and interview.

a. Questionnaire

The way data collected was crucial to the quality of the research taken. On the point of that, designing the questionnaire was a key part of survey research (Muijs, 2004). A questionnaire of this research was adapted from Akef and Moosavi (2014).The questionnaire consisted of close ended questions. The questions were divided into eight points, such as general appearance, design and illustration, accompanying materials, topic content, language contents, social and cultural contexts, language skills, and activities and exercises.

b. Interview

This research used interview as the research instrument to obtain further information besides questionnaire (Creswell, 2009). Semi structured interview was used to collect in-depth responses from the respondents and to set clear limits of questions in avoiding wider students' responses (Patton, 1990 in O'Donoghue and Punch, 2003; Heigham and Croker, 2009).

\section{Result}

This part provides a detailed analysis of the data obtained through the questionnaires in order to answer the first research question of the study.

1. General Appearance

A number of the scholars have highlighted the attractiveness of the physical appearance of the materials. Table 1 shows the results obtained from the perceptions of students about the general appearance of English for Professional Tour Guiding Services.

Table 1: Students' View about General Appearance

\begin{tabular}{|c|c|c|c|c|c|c|c|c|c|c|}
\hline NO & \multicolumn{2}{|c|}{1} & \multicolumn{2}{|c|}{2} & \multicolumn{2}{|c|}{3} & \multicolumn{2}{|c|}{4} & \multirow{2}{*}{ Mean } & $\begin{array}{c}\text { St. } \\
\text { Deviation }\end{array}$ \\
\hline & $\mathrm{F}$ & $\%$ & $\mathrm{~F}$ & $\%$ & $\mathrm{~F}$ & $\%$ & $\mathrm{~F}$ & $\%$ & & 1.95 \\
\hline 1 & 0 & 0 & 11 & 19 & 43 & 74 & 4 & 7 & 4.17 & 2.06 \\
\hline 2 & 0 & 0 & 5 & 9 & 45 & 78 & 8 & 14 & 4.42 & 2.20 \\
\hline 3 & 0 & 0 & 2 & 3 & 47 & 81 & 9 & 16 & 4.52 & 4.38 \\
\hline
\end{tabular}


As indicated in table 1, the mean scores for the statements related to this category ranges from 4.17 to 4.52. Most of the participants, in this case, agreed on the attractiveness of the general shape of the textbook. This result was similar to Aqel's (2009) or Moosavi's (2016) study which revealed that most of the students or teacher liked the attractiveness of the general appearance of a textbook.

\section{Design and Illustration}

Table 2 present the result of students' perception about the design and illustration of English for Professional Tour Guiding Services.

Table 2: Students' View about Design and Illustration

\begin{tabular}{|c|c|c|c|c|c|c|c|c|c|c|}
\hline NO & \multicolumn{2}{|c|}{1} & \multicolumn{2}{|c|}{2} & \multicolumn{2}{|c|}{3} & \multicolumn{2}{|c|}{4} & \multirow{2}{*}{ Mean } & \multirow{2}{*}{$\begin{array}{c}\text { St. } \\
\text { Deviation }\end{array}$} \\
\hline & $\mathrm{F}$ & $\%$ & $\mathrm{~F}$ & $\%$ & $\mathrm{~F}$ & $\%$ & $\mathrm{~F}$ & $\%$ & & \\
\hline 4 & 0 & 0 & 15 & 26 & 43 & 74 & 10 & 17 & 4.97 & 1.84 \\
\hline 5 & 0 & 0 & 23 & 40 & 28 & 48 & 7 & 12 & 3.95 & 1.32 \\
\hline 6 & 4 & 7 & 6 & 10 & 44 & 76 & 4 & 7 & 4.1 & 1.97 \\
\hline 7 & 0 & 0 & 11 & 19 & 40 & 69 & 7 & 12 & 4.25 & 1.76 \\
\hline 8 & 2 & 3 & 28 & 48 & 20 & 34 & 8 & 14 & 3.75 & 1.17 \\
\hline 9 & 4 & 7 & 22 & 38 & 26 & 45 & 6 & 10 & 3.75 & 1.11 \\
\hline 10 & 1 & 2 & 7 & 12 & 41 & 71 & 6 & 10 & 4.05 & 1.84 \\
\hline 11 & 4 & 6 & 10 & 17 & 39 & 47 & 3 & 5 & 3.82 & 1.11 \\
\hline \multicolumn{9}{|c|}{ Design and Illustration } & \multicolumn{2}{|c|}{4.08} \\
\hline
\end{tabular}

With regard to design and illustration, the participants' perception was quite good with total mean of 4.08. Among eight questions asked in this category, Question 8 and 9 got the lower mean compared to the other. Regarding Q8, most of the student thought that the illustration given on the textbook was not varied and creative. Some of the students also did not feel that the illustration given in a book pushed them to be creative (Q9). This statement was appropriate as there was no illustration or picture given in the textbook "English for Professional Tour Guiding Services". This book focused more on the practical skill of a tour guide. However, picture or illustration was needed to rise students' affective feeling. As Tomlinson (1998) states that material should take into account as it impacts learners' affective attitudes.

\section{Accompanying Material}

Table 3 summarizes the result of students' perception about the accompanying materials, such as CD or audio. 
Table 3: Students' View about Accompanying Materials

\begin{tabular}{|c|c|c|c|c|c|c|c|c|c|c|}
\hline NO & \multicolumn{2}{|c|}{1} & \multicolumn{2}{|c|}{2} & \multicolumn{2}{|c|}{3} & \multicolumn{2}{|c|}{4} & \multirow{2}{*}{ Mean } & $\begin{array}{c}\text { St. } \\
\text { Deviation }\end{array}$ \\
\hline & $\mathrm{F}$ & $\%$ & $\mathrm{~F}$ & $\%$ & $\mathrm{~F}$ & $\%$ & $\mathrm{~F}$ & $\%$ & & 1.19 \\
\hline 12 & 13 & 22,4 & 30 & 52 & 14 & 24 & 1 & 2 & 2.97 & 1.53 \\
\hline 13 & 31 & 53,4 & 24 & 41 & 2 & 3 & 1 & 2 & 2.22 & 2.60 \\
\hline
\end{tabular}

Finding presented in Table 3 indicated that most of the participants believed that a book was not equipped with suitable supplementary activities or CD. What the students' belief, in this case, was right. The evaluated book definitly did not provide a supplementary activity or CD. As stated in the background of the study, this book only focused on three language skill, which were speaking, writing, and reading. Students' listening skill here was not developed. The teacher sometime had to prepare the video to the use of CD-ROM and cassettes is one of the interesting and effective ways in the current generation of language teaching materials since they provide "the learners with opportunities to listen to the language being used" (Tomlinson, et al., 2001, p.90).

\section{Topic Content}

Table 4 presents the result of students' opinion toward the effectivenes of topic content in a book "English for Professional Tour Guiding Services".

Table 4: Students' View about Topic Content

\begin{tabular}{|c|c|c|c|c|c|c|c|c|c|c|}
\hline \multirow[t]{2}{*}{ NO } & \multicolumn{2}{|c|}{1} & \multicolumn{2}{|c|}{2} & \multicolumn{2}{|c|}{3} & \multicolumn{2}{|r|}{4} & \multirow[t]{2}{*}{ Mean } & \multirow[t]{2}{*}{$\begin{array}{c}\text { St. } \\
\text { Deviation }\end{array}$} \\
\hline & $\mathrm{F}$ & $\%$ & $\mathrm{~F}$ & $\%$ & $\mathrm{~F}$ & $\%$ & $\mathrm{~F}$ & $\%$ & & \\
\hline 14 & 0 & 0 & 12 & 21 & 38 & 66 & 8 & 14 & 4.25 & 1.64 \\
\hline 15 & 0 & 0 & 27 & 47 & 28 & 48 & 3 & 5 & 3.75 & 1.51 \\
\hline 16 & 4 & 7 & 17 & 29 & 30 & 52 & 7 & 12 & 3.9 & 1.17 \\
\hline 17 & 1 & 2 & 31 & 53 & 25 & 43 & 1 & 2 & 3.55 & 1.58 \\
\hline 18 & 0 & 0 & 5 & 9 & 46 & 79 & 7 & 12 & 4.4 & 2.12 \\
\hline \multicolumn{9}{|c|}{ Topic Contents } & \multicolumn{2}{|c|}{3.97} \\
\hline
\end{tabular}

The mean scores of the items related to this category show that the participants were satisfied with the topic contents of a book. However, compared to the other, Question 17 got the lower mean. Most of the students (53\%) thought that the topic in a book did not allow them to think critically. As material on evaluated book focused more on a practice, the writer here tended to 
give an instruction of how did a conversation in the realm of tour guiding services. In other words, what the writer provide in a book seems to be a standards. As a result, the students tended to follow the instruction or dialogue given on a textbook. On the other hand, Question 18 gainned the highest mean score than the other. The students here felt that the topic given in a textbook was realistic. This was because a book was design according to the real situation of tour guiding services.

\section{Language Contents}

The evaluation of language component has been stressed in many of textbook evaluation studies. Table 5 summarizes the result of the section related to the attitude of students' toward the language content of a book "English for Professional Tour Guiding Services".

Table 5: Students' View about Language Content

\begin{tabular}{|c|c|c|c|c|c|c|c|c|c|c|}
\hline \multirow{3}{*}{$\mathrm{NO}$} & \multirow{2}{*}{\multicolumn{2}{|c|}{1}} & \multirow{2}{*}{\multicolumn{2}{|c|}{2}} & \multirow{2}{*}{\multicolumn{2}{|c|}{3}} & \multirow{2}{*}{\multicolumn{2}{|c|}{4}} & \multirow{3}{*}{ Mean } & \multirow{3}{*}{$\begin{array}{c}\text { St. } \\
\text { Deviation }\end{array}$} \\
\hline & & & & & & & & & & \\
\hline & $\mathrm{F}$ & $\%$ & $\mathrm{~F}$ & $\%$ & $\mathrm{~F}$ & $\%$ & $\mathrm{~F}$ & $\%$ & & \\
\hline 19 & 10 & 17 & 24 & 41 & 22 & 38 & 2 & 3 & 3.3 & 1.04 \\
\hline 20 & 2 & 3 & 15 & 26 & 33 & 57 & 8 & 14 & 4.07 & 1.34 \\
\hline 21 & 25 & 43 & 24 & 41 & 8 & 14 & 1 & 2 & 2.52 & 1.19 \\
\hline 22 & 11 & 19 & 30 & 52 & 17 & 29 & 0 & 0 & 3.05 & 1.25 \\
\hline 23 & 0 & 0 & 11 & 19 & 38 & 66 & 9 & 16 & 4.3 & 1.64 \\
\hline 24 & 3 & 5 & 24 & 41 & 26 & 45 & 5 & 9 & 3.72 & 1.22 \\
\hline \multicolumn{9}{|c|}{ Language Contents } & \multicolumn{2}{|r|}{3.5} \\
\hline
\end{tabular}

Table 5 indicates the mean scores for the items related to this category ranges from 2.52 to 4.3 . One of the most striking findings of this study was that a majority of the participants (43\%) stated that a book did not include an adequate material for pronunciation work. This then supported by the students' answer that disagreed to the statement uttered in question 19, in which pronunciation wasbuilt through different types of activities, such as listening, speaking, reading, and writing. The fact showed that there was no vocabulary or pronunciation practice in a book "English for Professional Tour Guiding Services". The teachers, in this case, had to provide additional activity to develop students' vocabulary or pronunciation. They also had to give more attention while students did an activity in order to correct their phonological errors.

The highest mean score in this category was gained by Question 23. The students, at this point, agreed that the language contents in a book "English for Professional Tour Guiding Services" suited their language' needs. This was probably cause by the practical material offered by this book. 


\section{Social and cultural context}

The appropriateness of social and cultural is one of the mostly mentioned criteria in evaluating a textbook or teaching material (McDonough\&Shaw,2005). Table 6 presents the result of students' response related to the social and cultural context in an evaluated book.

Table 6: Students' View about Social and Cultural Context

\begin{tabular}{|c|c|c|c|c|c|c|c|c|c|c|}
\hline NO & \multicolumn{2}{|c|}{1} & \multicolumn{2}{|c|}{2} & \multicolumn{2}{|c|}{3} & \multicolumn{2}{|c|}{4} & Mean & $\begin{array}{c}\text { St. } \\
\text { Deviation }\end{array}$ \\
\hline & F & $\%$ & F & $\%$ & F & $\%$ & F & $\%$ & & \\
\hline 25 & 0 & 0 & 6 & 10 & 48 & 83 & 4 & 7 & 4.3 & 2.25 \\
\hline 26 & 1 & 2 & 17 & 29 & 37 & 64 & 3 & 5 & 3.95 & 1.66 \\
\hline 27 & 1 & 2 & 14 & 24 & 42 & 72 & 1 & 2 & 3.97 & 1.93 \\
\hline \multicolumn{8}{|c|}{} & \\
\hline
\end{tabular}

Table 6 shows that the participants a book very effective in terms of the social and cultural contexts. The highest mean in this category belongs to Question 27, in which $83 \%$ of the participants believed that the social and cultural context in a book was comprehensible.

7. Language Skill

Table 7 presents students' response to the language skill on a book "English for Professional Tour Guiding Services".

Table 7: Students' View about Language Skill

\begin{tabular}{|c|c|c|c|c|c|c|c|c|c|c|}
\hline NO & \multicolumn{2}{|c|}{1} & \multicolumn{2}{|c|}{2} & \multicolumn{2}{c|}{3} & \multicolumn{2}{|c|}{4} & Mean & $\begin{array}{c}\text { St. } \\
\text { Deviation }\end{array}$ \\
\hline & $\mathrm{F}$ & $\%$ & $\mathrm{~F}$ & $\%$ & $\mathrm{~F}$ & $\%$ & $\mathrm{~F}$ & $\%$ & & 2.00 \\
\hline 28 & 8 & 14 & 44 & 76 & 6 & 10 & 0 & 0 & 2.85 & 8.4 \\
\hline 29 & 15 & 26 & 21 & 36 & 17 & 29 & 5 & 9 & 3.2 & 1.64 \\
\hline 30 & 22 & 38 & 34 & 59 & 2 & 3 & 0 & 0 & 2.4 & 1.89 \\
\hline 31 & 1 & 2 & 12 & 21 & 42 & 72 & 3 & 5 & 4.07 & 2.07 \\
\hline 32 & 0 & 0 & 4 & 7 & 45 & 78 & 9 & 16 & 4.47 & 8.4 \\
\hline 33 & 5 & 9 & 24 & 41 & 23 & 40 & 6 & 10 & 3.65 & \\
\hline \multicolumn{7}{|l|}{ Language Skills }
\end{tabular}

It is evident from the table above that students' perceptions about the language skills of a book seemed to be positive. It should be mentioned that evaluating language skills is essential for most scholars. However, it is obvious from the results that the material designers ignored the importance of listening skill. It could be seen from the means score of question 30, which only 
got 2.4. This question was about listening material that was well recorded and accompanied by background information, question, and activities. This data seemed to support the previous data (3.1), by which there was no activities that develop students' listening skill.

\section{Exercises and activities}

Table 8 indicates the results obtained from the attitudes of students towards exercises and activities of the series.

Table 8: Students' View about Exercise and activities

\begin{tabular}{|c|c|c|c|c|c|c|c|c|c|c|}
\hline NO & \multicolumn{2}{|c|}{1} & \multicolumn{2}{|c|}{2} & \multicolumn{2}{c|}{3} & \multicolumn{2}{|c|}{4} & Mean & $\begin{array}{c}\text { St. } \\
\text { Deviation }\end{array}$ \\
\hline & $\mathrm{F}$ & $\%$ & $\mathrm{~F}$ & $\%$ & $\mathrm{~F}$ & $\%$ & $\mathrm{~F}$ & $\%$ & & 2.57 \\
\hline 34 & 0 & 0 & 4 & 7 & 53 & 91 & 1 & 2 & 4.27 & 1.96 \\
\hline 35 & 0 & 0 & 15 & 26 & 42 & 72 & 1 & 2 & 4.0 & 1.67 \\
\hline 36 & 2 & 3 & 11 & 19 & 39 & 67 & 6 & 10 & 4.12 & 1.66 \\
\hline 37 & 1 & 2 & 17 & 29 & 37 & 64 & 3 & 5 & 3.95 & 1.72 \\
\hline 38 & 3 & 5 & 9 & 16 & 40 & 69 & 6 & 10 & 4.12 & 1.26 \\
\hline 39 & 5 & 9 & 21 & 36 & 29 & 50 & 3 & 5 & 3.65 & 1.35 \\
\hline 40 & 6 & 10 & 18 & 31 & 32 & 55 & 2 & 3 & 3.65 & 3.97 \\
\hline
\end{tabular}

The mean values for the statements related to this category ranged from 3.25 to 4.27. As indicated in table 8, the highest mean value is for Item 34, in which $91 \%$ of the participants believed that a book provided a variety of a meaningful and mechanicalexercise and activities to practice language items and skills. The lowest value in the eighth category belongs to Item 39 and 40, where most of the participants believed that the series failed to provide models for final achievement tests.

\section{Conclusion}

Textbook is one of the learning materials commonly used by the teachers in the class. It is a kind of printed material that has important role in teaching and learning process particularly in the language classroom. It provides a useful resource for both teachers and students. Due to the importance of textbook, teacher definitely should be selective in choosing the textbook used in the classroom. They also should check the suitability of the textbook for the students through the evaluation. 
The finding from questionnaire data reveals that in general, students are satisfied view to the use of a book "English for Professional Tour Guiding Services". Regarding the strengths of a book, the students thought that the book has a good appearance, design and illustration, and topic content. A book also has good language content and provide fair social and cultural context. Concerning exercise and activities, most of the students agree that a book provided a variety of a meaningful and mechanical exercise and activities to practice language items and skills. Unfortunately, there are some weaknesses in this book based on students' opinion. This mainly related to the absent of activity or exercise that develop students' listening skill. The book also does not offer a supplementary activity, specifically that related to the use of audio or $\mathrm{CD}$. This weakness finally drives the writers to design the material of a tour guiding services that develop students' listening skill.

It is expected that the result of this study will beneficial for the following parties: 1) for students, it is expected that material designed from this study can be used as a reference to learn English for Tour Guide. Thus, it can improve their English competence in tour guiding services; 2) for English lecture, the material can be used as a reference to teach English for Tour Guide course.; 3) for English Language Education Program, it is expected that the material designed can fulfill the need of course modules in English Language Education Program of STKIP Siliwangi; and 4) For STKIP Siliwangi, with the availability of suitable course book, the students can manage their activity in the class. The teachers also have suitable handout so they will be more ready in teaching. The combination of these two things will finally create good quality of students in STKIP Siliwangi Bandung. 


\section{Reference}

Akef, K. and Moosavi, Z. (2014). Iranian EFL teachers' and students' textbook evaluation. The Iranian EFL Journal, 10 (6).

Chu Ying, C. and Young, K. 2011. The Centrality of using textbooks in teachers' work: Perceptions and use of textbooks in a Hongkong Primary School. The Asia Pacific Education Researcher Journal.16 (2).

Creswell. J. W. (2009). Research design: Qualitative, quantitative, and mixed method approaches. California: SAGE Publications, Inc.

Fraidan, A.A. (2012). Evaluation of Two ESP Textbooks.English Language Teaching.Vol. $5(6)$.

Harmer, Jeremy. (2001). The Practice of English Language Teaching. Pearson Education.

Heigham, J. \& Croker, A. R. (2009).Qualitative research in applied linguistics. New York: Palgrave Macmillan.

Muijs, D. (2004). Doing quantitative research in education. London: Sage Publication.

O'Donoghue, A. T. \& Punch, F. K. (2003).Qualitative educational research in action: Doing and reflecting. London: RoutledgeFalmer.

Tabaeifard, J,S. (2014). English Language Textbook Evaluation”English for The Students of Humanities (1). International Research Journal of Applied and Basic Science. Vol. 8 (2): Page 571-575. 